\title{
P 138
}

\section{女性労働者の健診項目・健康相談の選択}

- (1) 健診に関する健康教育による認識の変化

O荒木葉子 ${ }^{1)}$ 、苅田香苗 ${ }^{2)}$ 、山岡和枝 ${ }^{2)}$ 、田宮菜奈子 ${ }^{2)}$ 、矢野栄二 ${ }^{2)}$

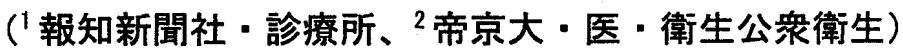

【はじめに】我が国では、健診（検診）は、職域、地域、個人レベルで広く行われている。しかし、受診 者が健診の内容についてどの程度理解しているのか、どんな検査・相談を必要と考えているのかなど受診者 側からの研究はほとんどない。今回我々は、EBM に基づく健康教育により、定期健診受診者の認識や選択パ ターンにどのような変化がおこるかのパイロットスタディを行ったので報告する。

【対象と方法】某組織の健康づくり事業「女性のための健康講座」参加者 45 名を対象とした。事前に基本 属性、健診·相談項目の知識の有無、自由選択 (項目数の制限なし) - 重要選択項目 (10 項目限定)について 問う無記名式質問票 (1) を配布し、回答後速やかに回収した。検査・相談項目の説明資料を配布するとともに、 約 1 時間スライドを用い、年秢に応じた疾患のリスクアセスメントと健診・相談項目内容に関する講義を行 つた。講義終了後、健診·相談項目の理解（講義により深まったか否か）、自由選択項目および重要 10 項目選 択を問う調查票 (2)を配布し回収した。

健診·相談項目は、一般定期健康診断、労災にて行う二次健康診断項目、通常の人間ドックで行われている 検查、US Preventive Service Task Force で推奖されている検查・相談項目を参考に50 項目を選択肢 とした。調查票集計前に講演者が講義内容の自己評価を行い、定期健診項目として内容が肯定的・中立的・ 否定的であったかのいずれかに50 項目を分類した。

【結果】有効回答者は 41 名、平均年齢 $45 \pm 7$ (28-59) 歳であった。

講義前に「健診内容を知っている」と答えた者が $20 \%$ 以下だった項目は、頸部超音波、尿アルブミン、マ ンモグラフィー、胸部ヘリカル CT、HbA1c、がんマーカー検査で、講義後に「理解が深まった」と回答した 者はこれらの項目では 44 80\%となった。各健診・相談項目における講義前後での自由選択率の変化を、講 義内容の方向性別に表 1 にまとめた。講義方向性が否定的であった項目は、講義前の選択率が平均で59\%で あったのに対し、講義後は $29 \%$ に低下した。胃内視鏡、貪血、マンモグラフィーについては講義の方向性と は一致しない結果となった。重要 10 項目の選択率は図 1 に示したように、講義前に比べ講義後に20\%以上

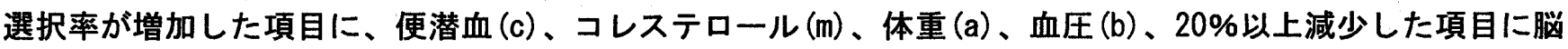
MRI $(G) 、$ 胸部レントゲン $(i) 、$ 脳 CT $(C)$ があげられた。

【考察】健診内容についての知識は、一般定期健診項目之通常の人間ドック項目で比較的高く、自由選択 でもこうした項目が選ばれる傾向があったが、健康相談項目はほとんど選択されなかった。講義後の選択は ほほ講義内容の方向性に治って変化し、診察・相談の選択も講義後には上昇したが、マンモグラフィーのよ うに変化しないものも認められた。講義前後でこうした評価を行うことにより、講義技術の改善にも役立つ ことが期待される。

表1. 講義内容の方向性亡自由選択率の変化

\begin{tabular}{|c|c|c|}
\hline $\begin{array}{l}\text { 請㧘内容の } \\
\text { 自己評価 }\end{array}$ & 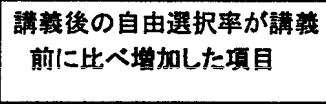 & 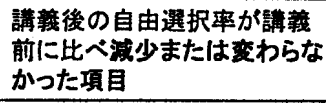 \\
\hline $\begin{array}{l}\text { 定期健形 } \\
\text { 項目として } \\
\text { 甚定的 }\end{array}$ & 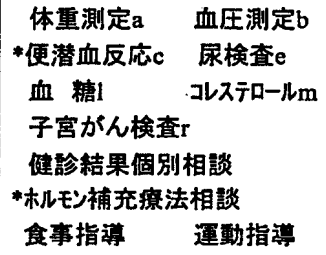 & 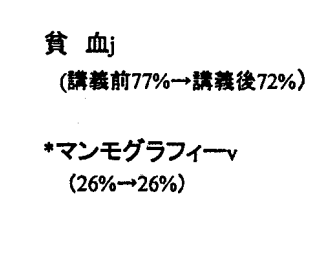 \\
\hline $\begin{array}{l}\text { 定期健診 } \\
\text { 項目として } \\
\text { 否定的 }\end{array}$ & 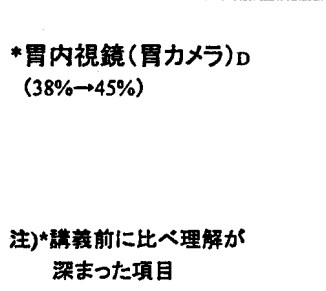 & 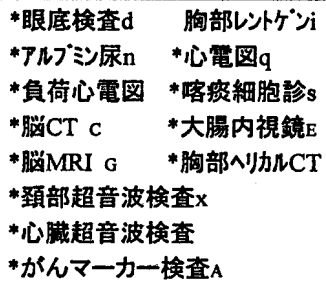 \\
\hline
\end{tabular}

\section{図1.重要10項目選択率の講義前後での変化}

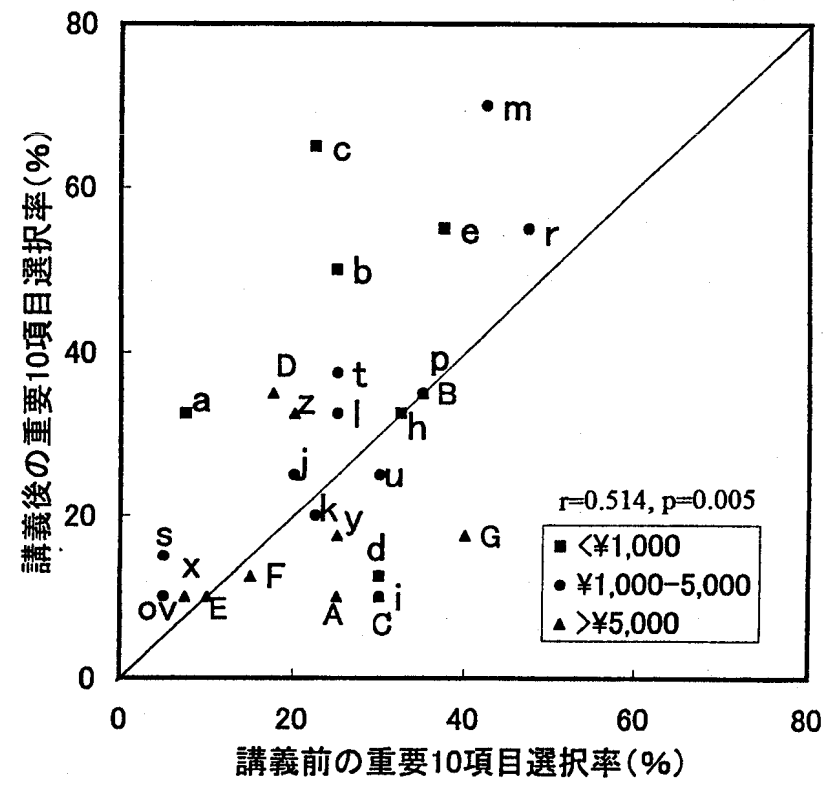

